\title{
Historein
}

Vol 15, No 2 (2015)

Historein 15/2 (2015)

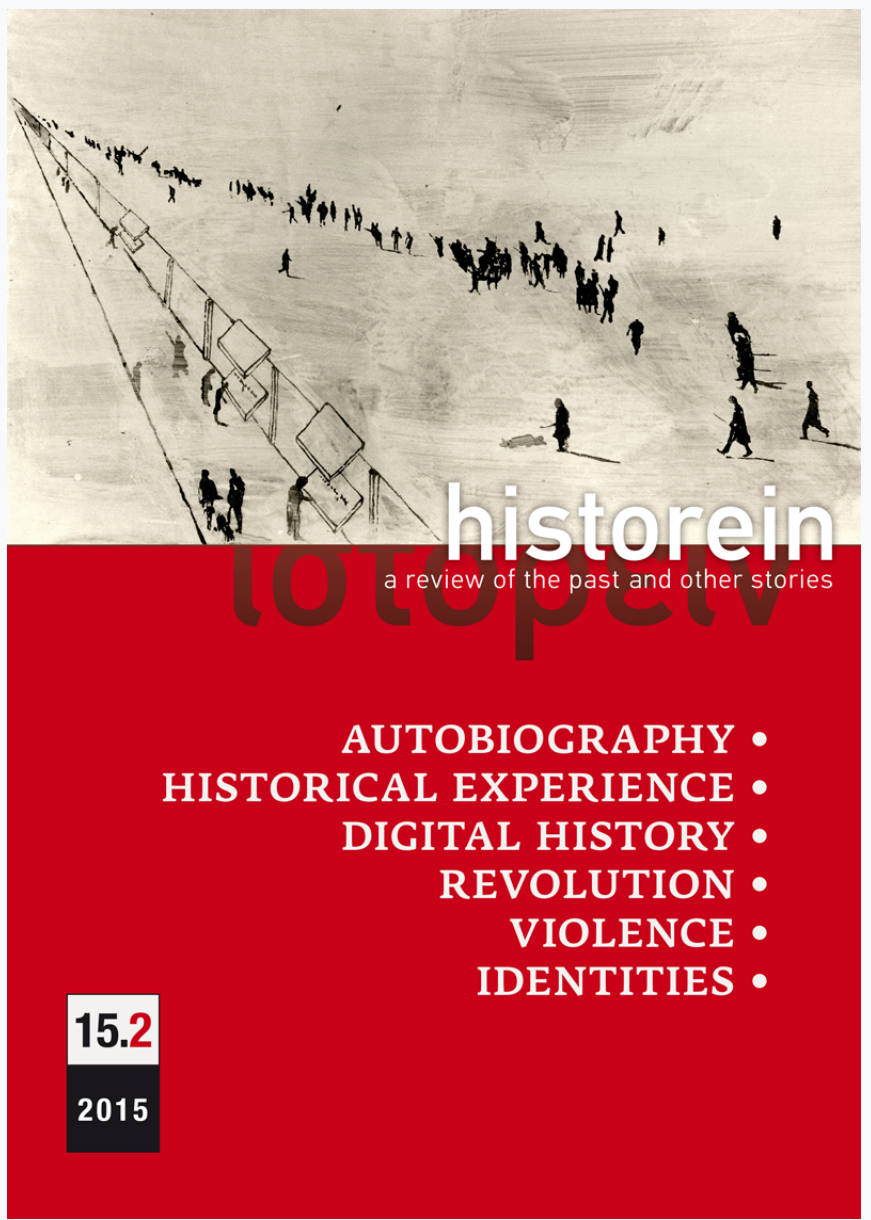

Review of Yannis Kondaratos', H $\theta \varepsilon \omega$ pía tou

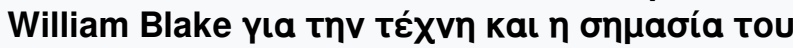

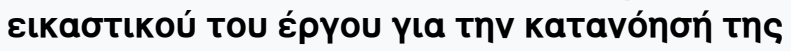
[William Blake's theory of art and the significance of his artwork for its understanding]

Elena Hamalidi

doi: $10.12681 /$ historein.8688

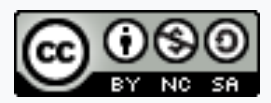

This work is licensed under a Creative Commons Attribution-NonCommercialShareAlike 4.0.

To cite this article:

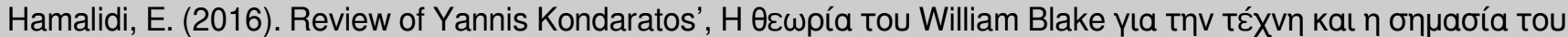

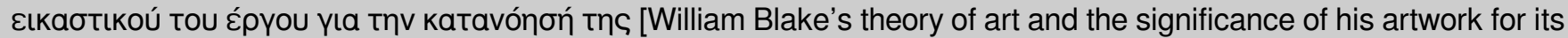
understanding]. Historein, 15(2), 103-106. https://doi.org/10.12681/historein.8688 


\section{Yannis Kondaratos}

\section{H Oewgía tov William Blake rıa tnv

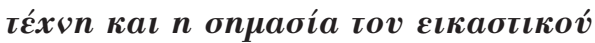 tov éerov rıa tnv katavónoń tns}

\section{[William Blake's theory of art and the significance of his artwork for its understanding]}

Athens: Nissos, 2013. 328 pp.

\section{Elena Hamalidi}

Ionian University

William Blake's work and words may have seemed heretical in his time; nevertheless, he has gradually emerged as a popular symbol of British identity. 'Moreover, contemporary scholars recognise in his art and theory images foretelling the present and ideas for the critical re-examination of our view on Enlightenment. $^{2}$

Yannis Kondaratos' interdisciplinary approach to Blake's painting and theory could be seen in the above context, since the author attempts a synthesis of Blake's art theory with his philosophical, religious and political views, in order to highlight the latter's place in history, that of a dissenter, who vehemently opposed the prevalent cultural and political discourses of his time. Kondaratos' monograph departs from his own fascination with Blake's art and art theory, which he recognises as an invaluable source for his own work as a painter. As he points out, Blake's art theory and artistic practice have been insufficiently studied, since most researchers focus mainly on his poetry, a fact that, as the author shows, has resulted in rather superficial interpretations of Blake's painting, theory and philosophical position alike. Hence, he undertakes a comprehensive comparative study of Blake's art and art theory with his poetry and poetic theory.

Kondaratos' main objective is threefold: he seeks to demonstrate the significance of Blake's theory for his painting, that Blake's poetic theory derives from his art theory, and that the interlinking of his theory and his artistic practice is connected to the radical character of his work. Thus, through his comparative study and the interdisciplinary approach applied as a whole, Kondaratos attempts to fill a research gap as well as to challenge a series of earlier interpretations.

The first chapter is on the "Life, the work and the time" of Blake. A particular section deals with Blake's exhibition of 1809 in his brother's store, its reception and the Descriptive Catalogue of Pictures, Poetical and Historical Inventions, written by the artist to accompany the exhibition as a kind of manifesto. The Catalogue is further analysed in later chapters.

The second chapter is a review of the "Reception of Blake's poetry and art work from his time to our days". What makes this chapter meaningful and useful for the general reader and the researcher alike is the careful historical presentation and critical evaluation of the relevant literature. Moreover, in this and the subsequent chapter (on Morris Eaves' 1982 book Blake's Theory of Art), Kondaratos introduces the reader to the theoretical part of his book and to his own methodological approach. To provide an example: Kondaratos' analysis of the role of visions in Blake's theory and work builds on Thompson's The Making of the English Working Class (1963), which associates the invocation of visions and prophecies with the radical ideology of popular religious groups. 
Kondaratos' own analysis of Blake partly departs from Eaves' treatise (the most important study of Blake's theory and art, according to Kondaratos). Namely, the author begins to elaborate his own theoretical approach in the third chapter ("The specificity of Blake's theory of the visual arts and the opposition to the 'study of nature'"), after he has presented Eaves' own arguments. Hence, Kondaratos' central thesis is based on the literal, not metaphorical - as Eaves argues - use of the terms "line" and "outline" by Blake in his texts. According to Blake, the drawing of figures, forms and volumes with legible lines and clear outlines allows the artist to feature reality "details" and to highlight the "character", "identity" and individuality of human figures; likewise, it allows the viewer to form his own, clear perception and understanding of reality. Blake's emphasis on the significance of line and outline is linked by Kondaratos to the painter's perception of the social function of art. Namely, Blake censures the reception of the Venetian school and the Flemish Baroque masters in Britain, for representing from memory single figures with blurred outlines by means of chiaroscuro. According to Blake, this deceitful manner can render the viewer a suitable victim of social oppression. The association of painting theory with politics by Blake and his contemporaries becomes clearer in one of the following chapters, developed thoroughly by Kondaratos. Here, the author takes English landscape painting as an example, showing, based on John Barrell (The Dark Side of the Landscape, 1979), that this manner of a "generalised" representation of figures through a standardised and popular use in England of chiaroscuro reproduced class divisions by placing, for example, the figures of poor peasants in the shadows.

On the contrary, Kondaratos argues that Blake's pursuit of "truth" had ethical dimen- sions, on the one hand, and was related to the painter's personal definition of imagination, on the other. Thus, Blake associates imagination, more specifically visionary imagination, with a "mental vision", which he juxtaposes with the "natural vision", and with "mental realism", which he juxtaposes with "the natural realism" of the Venetian Renaissance and the Flemish Baroque masters. Thus, visions for Blake, as Kondaratos observes, "are not of a supernatural character"; ${ }^{3}$ they are "aesthetic data" which enrich us with various points of view of the world (127). Based on Anthony Blunt (The Art of William Blake, 1959), S. Foster Damon (A Blake Dictionary: The Ideas and Symbols of William Blake, 1988) and Blake's texts, the author relates the idea of imagination as a liberating force from materialism with the Prophetic Books, and Blake's critique of Newtonian positivism and empiricism. In this as in other points, Kondaratos' contribution to the field becomes clear, as he fruitfully brings together interpretations of Blake's theory, or his religious and political positions, with his art.

The political aspects, social implications and philosophical position of Blake's painting theory and artistic practice are extensively presented by Kondaratos in the chapter on "Painting as a "technology of vision'". Here the focus is on Blake's critique of the "philosophy of politeness" prevalent in Britain during his era and of a dominant view, established by Shaftesbury along with the British Empiricists, of the moral impact that aesthetic refinement exercises on human conscience and social behaviour. In this context, the discourse on art espouses the discourse of political philosophy. The prevalent strategy then, in theory as well as in artistic practice, was the maintenance of an alleged social cohesion and the representation, through art, of social inequality as a natural condition. 
The above aesthetic position and the concomitant political views were represented at the time by one of the main addressees of Blake's criticism, Sir Joshua Reynolds, the first director of London's Royal Academy. Kondaratos analyses Blake's famous aggressive comments on Reynolds' Discourses, and attempts to relate them to Blake's art theory and political positions. He thus confutes Blake's identification with Reynolds' views, as well as with Neoclassicism, as argued by previous scholars.

It should be noted, nevertheless, that Blake also addresses issues related to national identity; he rejects the manner of a "vague" representation of reality in painting on the grounds that, since it was introduced in Britain by Rubens and Van Dyck, it was connected with the royal patrons and the interests of the ruling class, while it took the place of the painting tradition that followed Hans Holbein's portrait painting legacy.

On a parallel level, in the same chapter the author delves into Blake's critique of the Enlightenment. He "revisits" Newton, Locke, Bacon and Burke through the prism of Blake's own comments on their ideas, and attaches cohesion to the latter's theses; needless to say, Kondaratos is constantly challenged by Blake's poetic writing style.

The monograph's ending chapter deals with the "primitivist" characteristics of Blake's painting, as an aspect of Blake's criticism of the Enlightenment and, at the same time, as a forerunner of modernism. Interesting here is the elaboration of Blake's highly original attitude towards ancient art and his interest in other cultures. The book ends where it started, with the use of line in Blake's work and texts, and the re-examination of its relation to colour in Blake's painting.
In the epilogue, Kondaratos concludes with the conviction that TS Eliot's judgment, namely that "Blake's poetry has the unpleasantness of great poetry", also applies to his painting. This conclusion by the author brings us back to what seems to have been the incentive for writing this book. In the author's empathy with his subject, one can recognise, moreover, the merit of this demanding, in-depth study, and, at the same time, his own burden. Because, if Kondaratos does not aim at establishing Blake as a great painter - as he notes in his introduction - he, nevertheless, strives to achieve a synthesis of his aesthetic, political, ethical, religious and philosophical ideas and positions into a "coherent theory engaged in a dialectical discourse with the prevalent 'ideologemes' of the Enlightenment", even though he himself accepts that Blake "is not a systematic thinker" and that "the coherence he is in search of is not based on rational thinking" (22). For the reader this presumably constitutes an ambiguous aspect of this ambitious and captivating venture, which enthrals him by transposing him to a different world. Emerging from the book's pages is, indeed, on the one hand, a challenging if even contradictory personality, eager to confront authority and establishment, in order to defend his ideas, and on the other, a rather eclecticist art work, despite its stimulating theoretical point of departure.

Kondaratos achieves the most important of his goals, the reformulation of Blake's art theory in a stimulating way, establishing its connection with the artist's political and other positions, and also with his artistic practice. The fact that he applies an interdisciplinary approach and offers a comparative study of Blake's art and poetry as such makes this research a significant contribution on Blake.

As far as we can judge, the author also succeeds in challenging previous interpreta- 
tions of Blake's art which associated him with the Neoclassical movement. Moreover, Blake is highlighted here as an interesting, hybrid case, representative of a period whose transitional character complicates classification in standard binarisms (that is, NeoclassismRomanticism). Indeed, this book poses, through the investigation of Blake's case, a series of interesting issues as far as his period is concerned, such as the gradual autonomisation of art as a distinct field. Also, it stimulates reflection on the art of the Enlightenment.

It should be noted that the author's aim to attach cohesion to Blake's theory drives him to extensive analyses and further aims. For example, he sets out to prove that the representation of social relations in painting had an impact on the formation of the sociopolitical and philosophical discourse of the time. The fact, for instance, that Edmund Burke is influenced by a certain way of representation in painting is evidence for the relation of the political discourse with art discourse, but does not necessarily prove that the latter is shaped by the former. Equally, the provenance of Blake's poetic theory from his art theory cannot be sustained, since this issue is not investigated thoroughly and systematically.

In conclusion, Kondaratos' monograph on Blake indisputably enriches the Greek literature on the period. Most importantly, the emphasis on stylistic analysis and on the association of theory to artistic practice makes the author's contribution to Greek art historiography most notable. Despite the fact that this study discusses art specifically in Britain, its contribution to the understanding of eighteenth-century art and theory is invaluable. The book, written by a painter about another painter - and both of them are or have been theoretical and restless minds - could effectively add to the discussion on painting and on art history methodology.

\section{NOTES}

1 Martin Myrone, "Introduction," in Martin Myrone, ed., Seen in my visions: a descriptive catalogue of pictures by William Blake (London: Tate, 2009), 10.

2 WJT Mitchell, "World pictures: globalization and visual culture," in Jonathan Harris, ed., Globalization and contemporary art (Oxford: Wiley-Blackwell, 2011), 253-264. 